\title{
SILENCE IS GOLDEN: PUTTING YOURSELF IN THE PATIENTS' SHOES
}

Alessandra Soares Queiroz', Bruna de Abreu Porciúncula², Marina Ramos Baeta Neves ${ }^{3}$, Natália Carneiro de Freitas ${ }^{4}$, Rafaela Vieiralves João Izzo Pinto ${ }^{5}$, Sergio Zaidhaft ${ }^{6}$

'Medicine undergraduate student at Estácio de Sá University. Rio de Janeiro, Brasil. alessandra.olmo@gmail.com ${ }^{2}$ Medicine undergraduate student at Estácio de Sá University. Rio de Janeiro, Brasil. brunaporciuncula@outlook.com ${ }^{3}$ Medicine undergraduate student at Estácio de Sá University. Rio de Janeiro, Brasil. marina_baeta@msn.com ${ }^{4}$ Medicine undergraduate student at Estácio de Sá University. Rio de Janeiro, Brasil. nataliacdefreitas@gmail.com ${ }^{5}$ Medicine undergraduate student at Estácio de Sá University. Rio de Janeiro, Brasil. rafa_viip@hotmail.com ${ }^{6}$ MD. MSc in Psychiatry, Psychoanalysis and Mental Health. Professor at the Federal University of Rio de Janeiro and at Estácio de Sá University. Rio de Janeiro, Brasil. sergio.zaidhaft@gmail.com

RESUMO I Na tentativa de desenvolver empatia pelos pacientes, compreendendo melhor as limitações que sofrem e suas dificuldades de adesão às prescrições e proscrições, a matéria Relação Médico - Paciente do Curso de Medicina da Universidade Estácio de Sá solicita aos alunos do $5^{\circ}$ período a realização de uma tarefa grupal que consiste em sofrer, por certo tempo, as restrições impostas por alguma doença ou condição. Cinco alunas ficaram mudas por 48 horas. Feito o relato individual, cotejouse a experiência de todas e detectou-se o que houve de comum quanto à motivação e expectativas para o trabalho; reação de familiares, professores e colegas; sentimentos e reflexões suscitados pela experiência.

Palavras-chave: Empatia. Silêncio. Educação Médica. Pesquisa Qualitativa.
SUMMARY | In order to develop empathy for patients and to have a better understanding of their limitations and difficulties of compliance to prescriptions and proscriptions, the Doctor-Patient Relationship discipline of a Brazilian medical school asks its students to feel, for a certain time, the restrictions imposed by some disease orcondition. Five female students, self-defined as extremely talkative, remained silent for two days. An individual report was made, and the experience of all was checked in regards to: the motivation and the expectations for the work; the reaction of relatives, teachers and colleagues; the feelings and reflections provided by the experience.

Key-words: Empathy. Silence. Medical Education. Qualitative research 


\section{BACKGROUND}

A frequent complaint with regard to doctors is their lack of feeling or empathy as defined in terms of their reaction to other persons' emotional states. ${ }^{1}$

In order to help students feel empathy toward present and future patients, through a better understanding of a patient's limitations and difficulties when following prescriptions and proscriptions, the Doctor-Patient Relationship II course of Estácio de Sá University asked its 5 th-semester students to perform a group task that consisted in undergoing, for a predetermined amount of time, the restrictions imposed by such diseases or conditions as diabetis, hipertension, blindness, immobility of the dominant upper limb etc.

\section{SUMMARY OF WORK}

The class was divided into groups of up to 5 students. The all-female group made up by the present authors had to remain mute and refrain from any oral or otherwise verbal communication - such as texting - for two days, the first of which fell on Mothers' day, the second being a normal workday. Each student gave her own personal account, after which their experiences were compared and contrasted in terms of motivation and work expectations, the reactions of family members, teachers and peers, and the feelings and reflections caused by the whole experiment.

\section{SUMMARY OF RESULTS}

The topic was selected by the students in the group - who also happened to define themselves as extremely talkative - because of the challenges it posed. Most of the families supported the experiment and gave it positive reinforcement. But because of the anxiety which it also probably generated, some of the students' relatives reacted with scorn and even anxiety. Hence a number of peculiar situations, such as that of the five-year sister of one of the students, whose soundless gesturing led the little girl to believe that there were burglars in the house. A four-year boy was very distressed when his sister would not respond to his questioning, upon which he began shouting at her and shaking her in the hope that she might utter words.

Although aware of the fact that they had not lost the ability to express themselves orally and that they were ultimately free to quit and speak again, the students underwent moments of solitude and extreme anxiety in the course of the 48-hour experiment. They felt imprisoned inside themselves, given that they had previous, lived knowledge of what it was like to hear their voice fill the empty space and the void, but just did not know how to cope with the new reality.

Another finding was the awareness of the inexistence of social facilitators for patients suffering from this ailment. Equally noticeable was the lack of training to be found both in public and private establishments, as evinced by the negligible percentage of staff who can understand sign language.

Some of the students' peers dared them to keep silent and sought to make them speak, but eventually understood and offered help in class, trying to pay attention to even the slightest motion, which was then interpreted as part of a code. Most of the teachers were supportive. One of them, however, when told by other students, in class, about the reason for the group's silence, expressed his outrage and disbelief at the experiment's usefulness for prospective doctors, going, by acting this way, against the National Curriculum Guidelines for the study of Medicine. ${ }^{2}$

\section{TAKE-HOME MESSAGES / CONCLUSION}

The goal of understanding the suffering of those who cannot communicate orally was fully attained. Equally important and even more surprising, however, was the finding that silence led other people when next to the authors to talk more, which in turn led us to pay more attention to our own feelings rather than always having to come up with an immediate reply. In other words, silence allowed us to listen more attentively both to the other and to ourselves. 
Will the experiment live on in our minds, alongside the hidden curriculum that views empathy as superfluous? We certainly hope so, but who is to say? What we do know is that, unlike Hamlet, for whom silence is what is left after death, the brief time in our training that we devoted to silence and reflection is worth gold, for it made it possible for us to listen to ourselves. And that is absolutely necessary if we are to listen to our future patients.

\section{COMPETING INTERESTS}

No financial, legal or political competing interests with third parties (government, commercial, private foundation etc.) were disclosed for any aspect of the submitted work (including but not limited to grants, data monitoring board, study design, manuscript preparation, statistical analysis etc.).

\section{REFERENCES}

1. da Costa FD, de Azevedo RCS. Empatia, relação médicopaciente e formação em medicina: um olhar qualitativo. Rev Bras Educ Med. 2010;34(2):261-269. doi: 10.1590/S0100$\underline{55022010000200010}$

2. Brasil. Ministério da Educação. Conselho Nacional de Educação. Resolução n. 3, de 20 de junho de 2014. Institui Diretrizes Curriculares Nacionais do Curso de Graduação em Medicina e dá outras providências. Diário Oficial da União. 2014 jun. 23; Seção 1. p 8-11. 